\title{
Stop beating the donkey! \\ A fresh interpretation of conditional donkey sentences*
}

\author{
Aránzazu SAN GINÉS and María José Frápolli
}

Received: 10/02/2015

Final Version: 26/07/2016

BIBLID 0495-4548(2017)32:1p.7-24

DOI: $10.1387 /$ theoria. 13941

ABSTRACT: We propose a new approach to conditional donkey sentences that allows us to face successfully the often called proportion problem. The main ingredients of the proposal are van Benthem's generalized quantifier approach to conditionals (van Benthem, 1984), and Barwise's situation semantics (Barwise, 1989). We present some experimental data supporting our proposal.

Keywords: conditional donkey sentences; proportion problem.

RESUMEN: Proponemos una nueva aproximación a las oraciones condicionales burro, que nos permite hacer frente con éxito al llamado problema de la proporción. Los principales elementos de la propuesta son la aproximación de van Benthem a los condicionales como cuantificadores generalizados (van Benthem, 1984), y la semántica de situaciones de Barwise (Barwise, 1989). Presentamos algunos resultados experimentales que respaldan nuestra propuesta.

Palabras clave: oraciones condicionales burro; problema de la proporción.

\section{Introduction}

Classical predicate logic and the philosophy that supports it have proved to be powerful tools in the task of analyzing how language works. Nevertheless, even the best tools have their limitations, and the predicate calculus is no exception. In Begriffsschrift, Frege compared the contrast between natural language(s) and his proposed logical calculus to the con-

* Gabriel Sandu has been a great supporter of the research that has concluded with this paper. Allen Mann and Martin Andor have commented earlier versions of it and made insightful suggestions. Julio Santiago and his group from the University of Granada helped us with the experimental design. We also acknowledge the professional work and comments of the several reviewers of THEORIA who have shown us how to improve this paper. It is now much better thanks to their criticisms and advices. This work has been partly supported by the research group HUM-975 of the Plan Andaluz de Investigación, Desarrollo e Innovación (PAIDI) and by the project FFI2013-44836-P of the Ministerio Español de Economía y Competitividad. From 2014 on, Aránzazu San Ginés has enjoyed a Contrato de Formación Posdoctoral funded by the Ministerio Español de Economía y Competitividad. María José Frápolli has received funding from the European Union's Horizon 2020 research and innovation programme under the Marie Sklodowska-Curie Grant Agreement No. 653056. To all of them, people and institutions, we are deeply indebted. 
trast between the eye and the microscope. Even if the microscope is indispensable for some purposes, some others require a wider perspective. First order predicate calculus has difficulties accounting for the complexity of natural language(s). This is no news, but rather the background in which extended and non-standard logics find their rationale. Besides adding new operators or modifying the rules governing them, there are more radical ways of contesting the path that the predicate calculus has converted in the paradigm of logical reasoning. All the theoretical approaches that are nowadays classified under the general heading of 'Dynamic Semantics' have pointed out the difficulties of a static, satisfaction-based, semantic interpretation of the predicate calculus in accounting for the subtleties of our actual use of language. Our aim on the following pages will be to focus on a particular kind of sentences widely discussed by philosophers, linguists, and logicians for over fifty years, the socalled donkey sentences. We will analyze one problematic case of donkey sentence, and will propose a fresh interpretation for it that will eventually allow us to face successfully the often called proportion problem.

\section{Our Point of Departure: Conditionals}

We focus on donkey sentences of the following particular sort:

1. Simple (indicative) conditionals. Woods (1997: 9-10) described simple indicative conditionals as involving an application of 'If ... then ...' to a pair of sentences, each capable of being used to make an assertion on its own, and each expressing as part of the conditional what they would assert on their own.

2. The set of antecedent occasions is not empty (the antecedent happens). In 1984 van Benthem proposed to apply to the study of conditional statements the same methodological perspective that previously (cf. Barwise and Cooper, 1981) had been applied to study quantified sentences in linguistic semantics. That is, he proposed a generalized quantifier approach to conditionals (pp. 305-307). In this sense, "if $A$, (then) $B$; [is] regarded as expressing some semantic relation $\|$ if $\|(\|\mathrm{A}\|,\|\mathrm{B}\|)$ between the sets of antecedent and consequent occasions" (p. 306). An antecedent occasion (and analogously for consequent occasions) is an element of $\|\mathrm{A}\|$, being $\|\mathrm{A}\|$ the denotation of ' $\mathrm{A}$ '. For instance, given the classical example with which we will mainly work within this article 'If a man owns a donkey, he beats it', an antecedent occasion is a pair <man, donkey $>$ such that the man owns the donkey. $\|\mathrm{A}\|$ is the set of all antecedent occasions.

3. The universe of discourse, $E$, is finite ( $\|A\|$ and $\|B\|$ subsets of $E)$.

Our aim is to reveal some of the underlying mechanisms used in the interpretation of this sort of donkey sentences. For that, the main ingredients of our proposal will be the following:

a) We accept the generalized quantifier approach to conditionals, that is, our account will be provided in its terms. We have already noted the use that van Benthem (1984) makes of the generalized quantifier perspective in his analysis of conditional statements. In it, 'if denotes a generalized quantifier relation between sets of antecedent and consequent occasions (p. 304). However, it is obvious that not every possible relation qualifies as a relation of conditionality, so 
the question is: What are the relations that do qualify? In order to answer this question van Benthem introduces which he considers to be intuitive constraints on the relation (pp. 309-315). It follows that, for finite sets, only three possible relations accomplish all the requirements: those that could be naturally called 'all', 'half or more', and 'some' (p. 316). But this is an extremely restricted result which little has to do with the variety of accounts present in the literature on conditionals. In consequence van Benthem (pp. 318-320) proposes two ways out of the result, namely: $i$ ) the admission of infinite sets of occasions, or ii) the abandon of the intuition that prevents particular individual occasions from having special roles. The enrichment of the semantic structure can be done in two ways: iia) the introduction of probability measures on sets of occasions (inductive approach $)^{1}$, or iib) the differentiation of individual occasions through accessibility and similarity patterns (intensional approach). The account of conditional donkey sentences that we are going to defend in this article can be framed as an inductive approach in this sense. Hence the main ingredient that we will have to define throughout these pages will be an adequate measure of probability $\mathrm{P}$. Using this measure we will calculate two relevant values: $\mathrm{P}(\|\mathrm{A}\| \cap\|\mathrm{B}\|)$ and $\mathrm{P}(\|\mathrm{A}\|-\|\mathrm{B}\|)$.

b) We take seriously the active role of the agent in reading the environment (Barwise, 1989), i.e., we agree with situation semantics in that "[...] speech, writing, thought, and inference are situated activities. That is, they are activities carried out by intelligent, embodied, limited agents, agents situated in a rich environment, an environment that can be exploited in various ways" (Barwise, 1989: xiii). It is the agent who organizes her environment in a certain way, and hence considers some occasions more important than others. This idea will be present in our definition of P. We will provide here occasions with weights, and to do that we will need to take into account the configuration of the whole set of occasions. That means that in order to provide a particular occasion with a weight, we will first need to know what is the position or status of this occasion in relation to the others.

\section{Our Point of Departure: Ambiguities}

We can observe two kinds of ambiguities when we work with donkey sentences (see Bäuerle and Egli, 1985; Heim, 1990; Kanazawa, 1994; Schubert and Pelletier, 1989):

1. Existential and universal reading:

(a) If a man has a dime, he will put it in the meter.

(b) If a man has a dime, he will keep it.

The preferred reading of $(a)$ is the existential reading: if a man has dimes, he will put at least one of them in the meter (not necessarily all of them). On the other side, the preferred reading of $(b)$ is the universal one: as a rule of typical behavior, a man will always keep every dime he has.

1 Different occasions may have now different weights. 
2. Selective and non-selective quantification:

(c) Usually, if a man owns a donkey, he beats it.

We can distinguish here at least three potential readings of the sentence: (1) for most of the pairs <man, donkey> such that the man owns the donkey, the man beats the donkey; (2) most donkey-owners beat all of their donkeys; (3) most owned-donkeys are beaten by all of their owners. In (1) we are counting pairs, whereas in (2) and (3) the quantification is selective. Here, the adverb 'usually' acts on, respectively, 'a man', and 'a donkey'.2 $^{2}$

The proportion problem arose when it was realized that in certain contexts or situations, respectable semantic theories, as it is the Discourse Representation Theory (DRT), wrongly interpreted (c) as (1), an interpretation that was not at all intuitive in the particular contexts. The problem seemed to vanish though, when the dichotomy selective/ non-selective quantification was pointed out. That was indeed an important step forward, even though in our opinion the way in which selective quantification has been generally understood ever since is not the best possible one. In fact, the approach to donkey conditionals that we propose in this article, provides a different perspective from which to take into account both ambiguities. In the case of the proportion problem this new perspective yields a solution substantially different from the one generally associated with selective quantification. We maintain that our approach not only provides a new different interpretation to the sentences, but also that our interpretation seems to behave better in the sense that it provides more frequently the intuitive truth value of the sentences under consideration. In support of that we will introduce some experimental data in section 6.

In section 4. we will briefly present donkey sentences, and the main difficulties usually attached to them. In section 5 . we will expose the preliminary proposal which will eventually ease the introduction of our final proposal in section 7 .

\section{Donkey Sentences}

Donkey sentences were introduced into the philosophical debate by Peter Geach in the sixties (Geach 1962: 155-156), a topic that Geach brings in from the Middle Ages, and since then they have been a field in which every theory of quantifiers and pronouns in natural languages has had to test its merits.

Donkey sentences have proved to be particularly resistant to logical treatment. Their trademark is the co-existence of logical operators, indefinites, and anaphoric links. One usual example is the one already mentioned before:

(1) If a man owns a donkey, he beats it.

2 Observe that there is no room for universal/existential ambiguity when the preferred reading of a donkey sentence is the non-selective one. Observe also that (2) and (3) are selective as well as universal readings. 
We may refer to two main difficulties attached to donkey sentences:

a) The problem of the interpretation of indefinites. A quantificational interpretation of the indefinites is questioned by the presence of anaphoric pronouns outside the corresponding quantificational scope, which instead seems to call for a referential interpretation. Since the 80 's several proposals have emerged to combine and unify both interpretations (dynamic theories, arbitrary objects...).

b) The meaning of donkey sentences. As already mentioned before donkey sentences are ambiguous, and the resolution of these ambiguities is not easy. In relation to the existential/universal ambiguity, for instance, its resolution seems to depend on two factors: "the initial determiner and world knowledge" (Geurts, 2002: 130). Observe that Geurts works mainly in his article with relative donkey sentences (e.g. "Every farmer who owns a donkey beats it"), hence that he speaks of determiners. In the case of conditionals however what we could say instead is that the preferred interpretation depends on the initial adverb (usually, seldom, etc.), if any, and also of course on world knowledge.

In this article we are not directly concerned with neither of these difficulties. Our work begins after the right reading (universal/existential-selective/not-selective) has been established. Our concern is with the way of counting. How shall we understand a universal reading? And an existential one? Is the selective quantification approach as it is usually understood really a solution to the proportion problem?

\section{The Proportion Problem. Preliminary Proposal}

As we already said in section 3, the proportion problem arises when, in certain contexts a simple counting of pairs is used to interpret donkey sentences like the following:

(2) Usually, if a man owns a donkey, he beats it.

Take for example what happens with dynamic semantic theories like Discourse Representation Theory (DRT). This theory predicts that (2) will be true, given a model, if most pairs of occasions constituted by a man and a donkey where the first owns the second, have the relation of 'beating' between the man and the donkey. This prediction, says King (2010) (cf. Heim(1990)), seems to be intuitively false in the case of a model in which there are exactly ten donkey owning men, where one man owns ten donkeys and beats them all, while the nine other men own each a donkey and do not beat them. Under the DRT interpretation, sentence (2) is true in the model, notwithstanding the intuition. The problem here is that the truth-value assigned to the conditional depends directly upon the sum of isolated occasions, something that seems clearly inappropriate.

What is the difference then with our approach? As we indicated in section 2., one fundamental feature of our approach is the assignment of weights to particular occasions according to the configuration of the whole set of them. More precisely, for us a configuration is a set of very particular functions that we call relevant functions. Let us explain these notions using sentence (2) as example:

(2) Usually, if a man owns a donkey, he beats it. 
A relevant function - for (2) - is defined as a function,

$$
f:\{x \in \text { Man: } \exists y \in \text { Donkey } \&<x, y>\in \text { Own }\} \rightarrow\{y \in \text { Donkey: } \exists x \in \text { Man } \&<x, y>\in \text { Own }\}
$$

where each $x$ is associated with $y$ only if $x$ Owns $y$ in the model, and which is imposed to be as injective as possible. That means, in the case of (2), that each donkey-owner is associated (through $f$ ) with a donkey that is not associated, if possible (see below), with any other man. Let us call Rngx the domain of the function $f$ - the set of donkey owners in the model's domain - and Rngy the codomain of $f$-the set of donkeys owned by a man also in the model's domain. Finally, we call $C$ (configuration) the set of all the relevant functions.

It is time now to introduce our preliminary proposal, according to which sentence (2) will be true if and only if:

(1) most off: Rngx $\rightarrow$ Rngy s.t.

(2) $<x, f(x)>\in O$ wn \&

(3) $\forall v \forall w[f(v)=f(w) \rightarrow(v=w$ or $(\nexists a \in R n g y:<w, a>\in O w n \& \forall z f(z) \neq a))]$

(4) most of $x(<x, f(x)>\in$ Own $\rightarrow<x, f(x)>\in$ Beat $)$

Lines (2) and (3) define what a relevant function for (2) is. (3) makes explicit the idea of a function imposed to be as injective as possible. Finally, two quantifiers are here at work: one ranging over $C$ (the set of all relevant functions) (1), and another ranging over the graph (set of occasions) of the different relevant functions (4).

\section{Three observations}

1. The first observation is in fact a clarification. We are assuming in this article an interpretation of 'usually' as 'mostly'. Of course, this is a valid assumption in some contexts, but not in others. The expectations of the speakers play an important role here. For instance, it is not necessary to have a majority of vegetarians living in a country $A$ in order to find people who plainly accept that you usually meet vegetarians in country $A$. It would be enough that these people come from another country $B$ with a rate of vegetarians much lower than the rate of vegetarians in $A .{ }^{3}$ In any case, this fact does not affect our reasoning. Remember what we said in section 4.: our concern is with the way of counting, a different way of counting which affects the way to understand, and thus to take into account, the ambiguities. Our concern is not with 'how many occasions', but with the way of counting these occasions.

2. This interpretation yields the intuitive truth value of (2) when it is uttered under the problematic context $(\mathrm{T})$ :

10 donkey owning men

(T) 9 men own a donkey each and do not beat them

1 man owns 10 donkeys and beats them all

3 We would like to thank David Rodríguez-Arias for the beautiful example. 


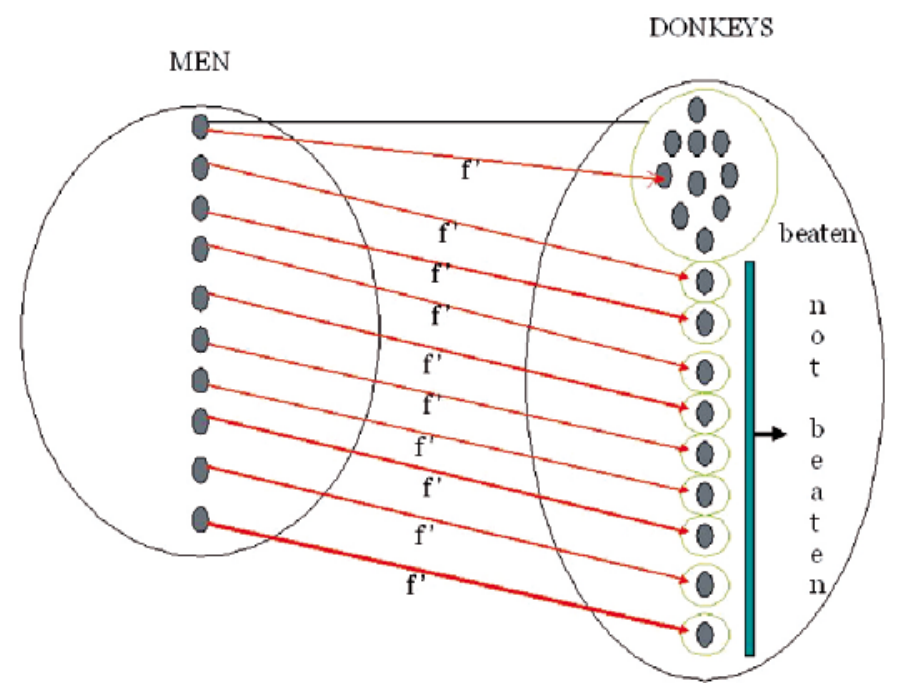

According to the just provided proposal sentence (2) is false under these conditions. There are ten different relevant functions $f(\mathrm{f}$ is one of them). Given a relevant function, the pairs $<$ man, donkey $>$ in its graph will be those used to evaluate:

(4) most of $x(<x, f(x)>\in$ Own $\rightarrow<x, f(x)>\in$ Beat $)$

To refute (2) it is enough to observe that for any relevant function $f$ there is only one pair in its graph such that $\langle x, f(x)\rangle \in$ Beat. Consequently, (4) is not satisfied.

3. This interpretation allows to distinguish between the following two sentences:

(2) Usually, if a man owns a donkey, he beats it.

(3) Usually, if a donkey is owned by a man, it is beaten by him.

(3) can be interpreted, analogously to (2), as:

most of $f:$ Rngx $\rightarrow$ Rngy s.t.

$$
\begin{aligned}
& <x, f(x)>\in \text { Owned \& } \\
& \quad \forall v \forall w[f(v)=f(w) \rightarrow(v=w \text { or }(\nexists a \in \text { Rngy }:<w, a>\in \text { Owned } \& \forall z f(z) \neq a))] \\
& \text { most of } x(<x, f(x)>\in \text { Owned } \rightarrow<x, f(x)>\in \text { Beaten })
\end{aligned}
$$

where Rngx is now the set of donkeys owned by a man and Rngy is the set of donkey owners in the model's domain.

With regard to the same context (T) under which (2) was false, (3) is now intuitively true. And again, our approach corresponds to intuition: there is only one relevant function $f$, and in its graph we can distinguish 19 pairs < donkey, man> of which ten are such that the man beats the donkey. 


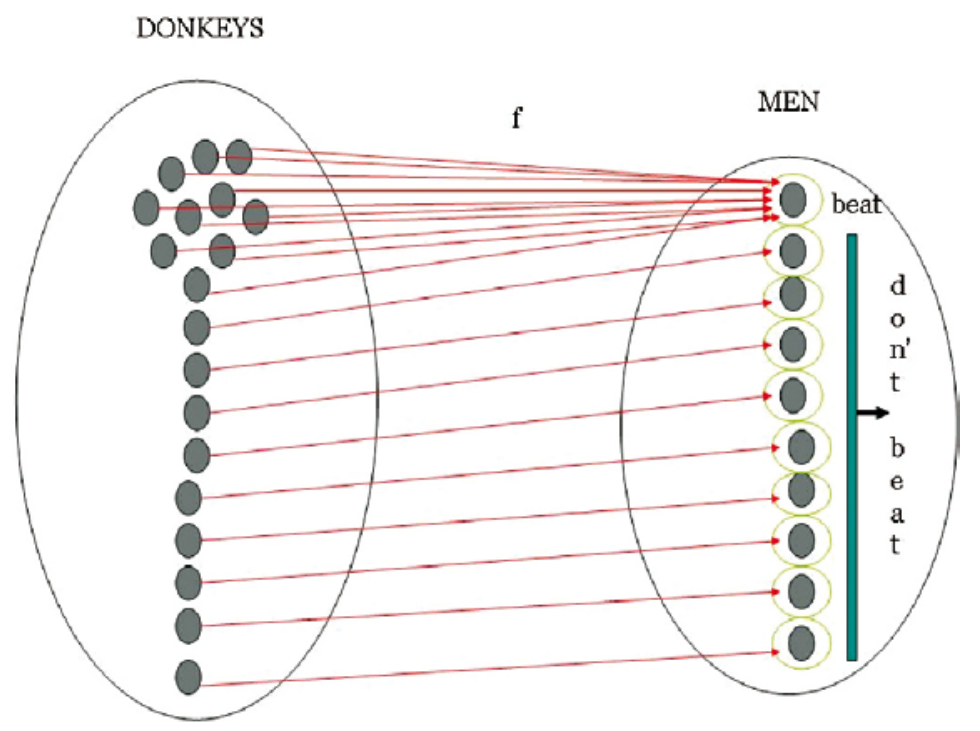

So far, it could seem to the reader that the present proposal is just a quite unorthodox way of talking of the very usual idea of selective quantification. ${ }^{4}$ The difference between active and passive that we have pointed out above, for instance, would be no more than a reflection of the more prominent status of one indefinite over the other during the interpretation process, a prominent status that in our preliminary proposal would be peculiarly expressed through the selection of the elements of Rngx and Rngy. Take as example the following sentence (Chierchia, 1992: 121):

(4) Dolphins are truly remarkable. When a trainer trains a dolphin, he usually makes it do incredible things.

Given the more prominent interest of the indefinite 'a dolphin' over 'a trainer' in the second sentence (the sentence preceding it being the reason), in our interpretation of 'When a trainer trains a dolphin, he usually makes it do incredible things', Rngx will be a set of dolphins, while Rngy will be a set of trainers. This would be just our peculiar way to express the prominence of 'a dolphin' over 'a trainer'.

The question thus is the following: Is it really then the very same and generally accepted idea of selective quantification which is also into play in our preliminary proposal? The answer is no. Once the selection of the indefinite has been made, and that we have defined Rngx and Rngy according to it, the treatment varies drastically from the generally accepted one. The proposal is in fact an essentially different and new one as we will see in the next section.

4 For an interesting discussion and proposal dealing with the proportion problem through selective quantification, see (Chierchia, 1992). 


\section{A Better Approach}

Is the preliminary solution that we have exposed in the previous section a really different and better one to the proportion problem? In order to answer this question we have run an experiment among two groups of students of the University of Granada (Spain). In the experiment, we confronted the students with a written test ${ }^{5}$ in which we provided them with the description of two particular situations. The students were asked to read the situations carefully, and after that to judge whether or not they considered a conditional donkey sentence to be true in each one of the situations described. The first of the provided contexts (once translated to English) is the following:

\section{Context and question 1:}

You are visiting a small village with a very small population. Among them, 17 are men and all of them work the land with the help of animals. The 17 men are donkey-owners, and their relation with their donkeys is the following:

-8 men own one donkey each. All of them treat badly their donkeys.

- Among the remaining 9 men, we can find the Sánchez, the Pérez, and the Martínez.

The Sánchez brothers are 2 and they have one donkey each (the donkeys are called Tim and Tom respectively), which also belong to their father. The two brothers treat well their respective donkeys.

The father of the Sánchez brothers owns three donkeys (Tim, Tom, and another one). The man treat well Tim and Tom, but he treats badly his other donkey.

The situation is repeated again with the Pérez:

The Pérez brothers are 2 and they have one donkey each (the donkeys are called Tipi and Topo respectively), which also belong to their father. The two brothers treat well their respective donkeys.

The father of the Pérez brothers owns three donkeys (Tipi, Topo, and another one). The man treat well Tipi and Topo, but he treats badly his other donkey.

The situation is repeated a last time with the Martínez:

The Martínez brothers are 2 and they have one donkey each (the donkeys are called Trini and Troco respectively), which also belong to their father. The two brothers treat well their respective donkeys.

The father of the Martínez brothers owns three donkeys (Trini, Troco, and another one). The man treat well Trini and Troco, but he treats badly his other donkey.

\section{Question:}

In which concerns this small village, would you say that the following claim is true?

"In this small village, mostly, if a man owns a donkey, he treats it badly"

Choose the answer that seems more intuitive to you rounding only one of the two options that follows.

YES NO

5 The original test as well as an English translation of the second context can be found in the Annex. 
The general way to understand selective quantification together with the universal reading predicts the answer to this question to be NO: Out of the 17 men of the village, most of them, 9, are such that they do not treat badly all their donkeys.

As for our preliminary proposal, it predicts the answer to be YES. The reason is that the graph of the only relevant function here $f$ contains 17 pairs < donkey, man $>$ of which most of them, 11, are such that the man treats badly the donkey.

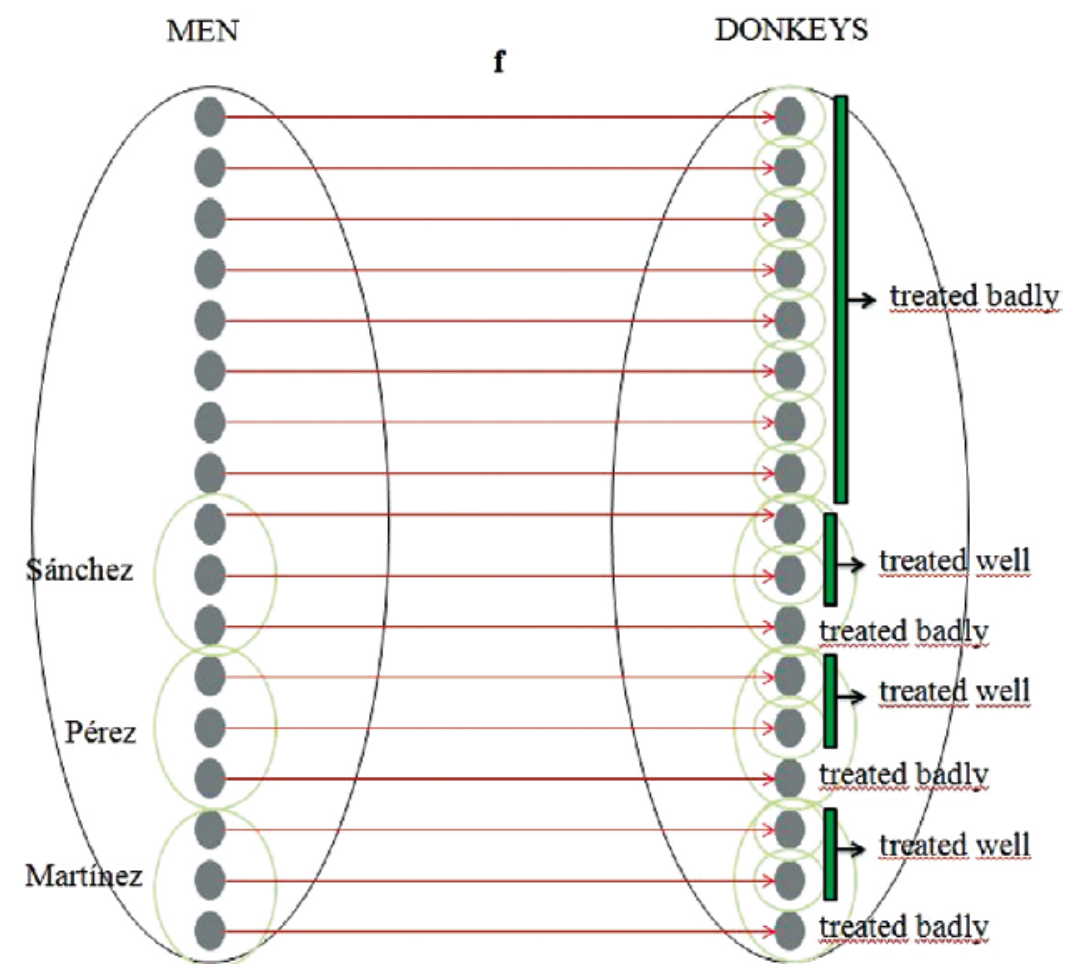

What about the other six pairs of < donkey, man $>$ that we are not considering? What about the pair <father Sánchez, Tim > for example? Our approach predicts that this pair is not going to have any weight in the decision. Remember that our relevant functions are imposed to be as injective as possible.

Both proposals are clearly differentiated by the proposed context. Now, what were the answers of the participants? We asked the questions to two different groups: one (group A) in which there were 18 native speakers of Spanish, and another (group B) in which there were 35 native speakers of Spanish. The results we got were the following:

\begin{tabular}{lcc}
\hline & Group A & Group B \\
\hline YES & 12 & 24 \\
NO & 6 & 11 \\
\hline
\end{tabular}


These results ${ }^{6}$ seem to single out our proposal as the closest to the speakers' intuitions. However, someone could still tell us that this is just a particular example. Maybe the usual way to understand selective quantification does not work completely well with universal readings, but what about existential ones? Let us consider for a moment the following example (Chierchia, 1992: 130):

(6) Usually, if a man has a dime, he will put it in the meter.

Clearly, our approach seems to work badly here. What is the reason? Our interpretation provides a new account of the universal reading, but not of the existential one. Our problem then is to find a way to account for the existential reading in our formalism. The answer is simple: In the construction of the set Rngy corresponding to (6) $(R n g y=\{y \in$ Dime $: \exists x \in$ Man $\&<x, y>\in$ Has $\})$ we will count all dimes had by the same man as just one (the one which will be put in the meter, if there is some; any dime, otherwise). There will be then only one relevant function, and the interpretation will be the same one than the provided by the usual selective quantification.

\section{Final step. Our proposal}

At the beginning of the article (section 2.) we introduced those which we claimed to be the main ingredients of our proposal, namely: a) a generalized quantifier approach to conditionals, and b) an active role of the agent in reading the environment. The idea then was to define an adequate measure of probability $\mathrm{P}$ in order to use $\mathrm{P}(\|\mathrm{A}\| \cap\|\mathrm{B}\|)$ and $\mathrm{P}(\|\mathrm{A}\|-\|\mathrm{B}\|)$ to interpret the conditionals. The active role of the agent in reading the environment would be at play in the definition of $\mathrm{P}$.

Our preliminary proposal has had a double role, that of introducing the tools we needed to define $\mathrm{P}$, and that to ease the understanding of our final proposal. We said in section 2. that in order to define $\mathrm{P}$ we would provide occasions with weights. To do that, we promised to take into account the configuration of the whole set of occasions. Well, the way we are going to do that is via the relevant functions.

So far, given the difficult case of a donkey sentence such as:

(2) Usually, if a man owns a donkey, he beats it,

we have proposed the following interpretation:

(2) is true iff

most of $f:$ Rngx $\rightarrow$ Rngy s.t.

$<x, f(x)>\in$ Own \&

$\forall v \forall w[f(v)=f(w) \rightarrow(v=w$ or $(\nexists a \in R n g y:<w, a>\in O w n$ \& $\forall z f(z) \neq a))]$

most of $x(<x, f(x)>\in$ Own $\rightarrow<x, f(x)>\in$ Beat $)$

Let us call this interpretation (I1).

6 Look at the Annex for a more detailed exhibition of the results. 
Now, our final proposal (cf. van Benthem, 1984: 322-326) goes as follows:

(2) is true iff $\mathrm{P}(\mathrm{A} \cap \mathrm{B})>\mathrm{P}(\mathrm{A}-\mathrm{B})^{7}$,

where:

A is the set $\{\langle x, y\rangle: x \in$ Man, $y \in$ Donkey, $\langle x, y\rangle \in$ Own $\}$,

$\mathrm{B}$ is the set $\{\langle x, y\rangle: x \in$ Man, $y \in$ Donkey, $\langle x, y\rangle \in$ Beat $\}$, and

$\mathrm{P}$ is a probability measure assigning probabilities to set of occasions of $\mathrm{A}$ in the following way:

$$
\begin{aligned}
& \mathrm{P}(\varnothing)=0, \\
& \mathrm{P}(<x, y>)=\# \mathrm{G}_{\langle x, y>} / \# \mathrm{G}, \text { and } \\
& \mathrm{P}\left(\mathrm{A}^{\prime}\right)=\Sigma_{\left(<x, y>\in \mathrm{A}^{\prime}\right)}\left(\# \mathrm{G}_{<x, y>} / \# \mathrm{G}\right),
\end{aligned}
$$

where:

$\varnothing$ is the empty set,

\# expresses cardinality,

/ expresses quotient,

$\Sigma(\ldots)$ is the summation sign,

$C$ (configuration) is the set of all relevant functions,

$n:=$ Number of relevant functions,

$<x, y>\in \mathrm{A}$,

$\mathrm{A}^{\prime}$ is a subset of $\mathrm{A}$,

$\mathrm{G}$ is a disjoin union: $\mathrm{G}:=\coprod_{f \in C} \operatorname{Graph}(f)=\{(<x, f 1(x)>, f 1), \ldots,(<x, f n(x)>, f n), \ldots\}$,

$\mathrm{G}_{\langle x, y\rangle}:=\{(<x, f i(x)>, f i): 1 \leq i \leq n \& f i(x)=y\}$.

The idea in fact is very simple: The weight of an occasion $\langle x, y\rangle, \mathrm{P}(\langle x, y\rangle)$, is the proportion of times that $\langle x, y\rangle$ appears in the whole of graphs of the different relevant functions. For example, if $\langle x, y\rangle$ does not appear in any of the graphs of the relevant functions, $\mathrm{P}(<x, y>)$ will be 0 .

Let us call our final proposal (I2).

We can observe that (I1) and (I2) give the same answer to any of the examples so far. Hence the following question arises naturally: Are our preliminary and final proposals actually the same? It seems clear that if (2) is true according to (I1), then it is also true according to (I2). The converse, unfortunately, does not hold. In order to verify this, it is enough to consider the next context:

-2 donkey owning men

- One of them owns 2 donkeys. He beats one but not the other.

- The other man only owns a donkey and he beats it

(2) is intuitively true under these conditions. This is the truth value attributed to it by our final proposal, but not by our preliminary one. (I2) improves (I1). Actually, (I2) is the most accurate expression of the ideas already present in (I1).

7 Observe that the relation between $\mathrm{P}(\mathrm{A} \cap \mathrm{B})$ and $\mathrm{P}(\mathrm{A}-\mathrm{B})$ can change depending on the initial adverb. If instead of 'usually' the adverb were 'seldom' for example, the inequality between the two probabilities would, at least, change direction $(\mathrm{P}(\mathrm{A} \cap \mathrm{B})<\mathrm{P}(\mathrm{A}-\mathrm{B}))$. 


\section{Conclusion}

We have fulfilled our aim. We have proposed a new perspective from which the two kinds of ambiguities proper to donkey sentences (universal/existential reading - selective/not-selective quantification) are given a new light. Our interpretation of (2) works, and we think that the main reason for that may be our resolution to take seriously the active role of the agent as perceiving his environment. The environment is not captured by the agent as a set of isolated elements, objects or occasions, but on the very contrary as an organized whole. The whole is really greater than the sum of its parts, and we think that it is necessary to take it into account if we are really interested in understanding natural language better and deeper.

Annex: test, results and controversy

You can find here the original test we used with the two groups of students, followed by the translation to English of the second context and question, and the results we got.

\section{THE TEST}

\section{CONSENTIMIENTO INFORMADO}

Gracias por tomar parte en esta investigación que se realiza auspiciada por el Departamento de Filosofía 1 de la Universidad de Granada. En ella rellenarás un breve cuestionario y responderás a un par de preguntas (duración estimada: 10 minutos). No se recogerá tu nombre, por lo que será imposible vincular tus respuestas con tu identidad. No hay respuesta correcta o incorrecta. Simplemente expresa cuáles son tus intuiciones.

Te puedes retirar del estudio en cualquier momento sin necesidad de dar ninguna explicación. Si tienes cualquier pregunta plantéasela al experimentador.

Firma aquí para mostrar tu consentimiento a participar en este estudio una vez leídas y entendidas las instrucciones anteriores:

Ciudad:

Fecha:

Firma:

\section{INSTRUCCIONES}

\section{NO HAGAS NINGÚN DIAGRAMA, DIBUJO O ANOTACIÓN}

1. Verás que las preguntas que se te hacen van precedidas de un contexto que te sitúa en un lugar y situación muy concretas.

2. Lee el contexto con atención. Lee la pregunta. Vuelve a dar un repaso rápido al contexto. Responde a la pregunta.

3. Recuerda que no hay respuesta correcta. La respuesta que te parezca mejor, sea la que sea, es la buena. Tampoco hay trampa alguna así que no la busques porque no existe. 
No hagas diagramas, ni anotaciones, ni dibujos. Simplemente cuenta (si lo necesitas) y responde a la pregunta.

Después de leer esta página pasa a la siguiente sin mirar la que le sigue.

Firma aquí para atestiguar que has leído y comprendido la información contenida en estas instrucciones:

Firma:

\section{Datos demográficos}

Lugar y fecha:

Iniciales - Día de nacimiento - Mes de nacimiento:

Sexo (Mujer u Hombre):

Año de nacimiento:

País de nacimiento:

País actual de residencia:

Lengua materna:

CUANDO HAYAS TERMINADO, DA LA VUELTA A LA HOJA. ANTES DE HACERLO RECUERDA QUE DEBES SEGUIR LAS INSTRUCCIONES DE LA PÁGINA PRECEDENTE. SI NO LAS RECUERDAS VUELVE A LEERLAS.

\section{Contexto y pregunta 1:}

Estás de visita en una aldea con muy pocos habitantes. De ellos, 17 son hombres y todos trabajan en el campo con la ayuda de animales. Los 17 hombres tienen burro y su relación con ellos es la siguiente:

- Hay 8 que tienen un burro cada uno. Todos ellos tratan mal a su burro.

- Entre los 9 restantes nos encontramos con los Sánchez, los Pérez y los Martínez.

Los hermanos Sánchez son 2 y tienen un burro cada uno (los burros Tim y Tom respectivamente), los cuales a su vez pertenecen también a su padre. Los dos hermanos tratan bien a sus respectivos burros.

El padre de los hermanos Sánchez tiene tres burros (Tim, Tom y un burro más). El hombre trata bien a Tim y a Tom, pero trata mal a su otro burro.

La situación se repite de nuevo con los Pérez:

Los hermanos Pérez son 2 y tienen un burro cada uno (los burros Tipi y Topo respectivamente), los cuales a su vez pertenecen también a su padre. Los dos hermanos tratan bien a sus respectivos burros. 
El padre de los hermanos Pérez tiene tres burros (Tipi, Topo y un burro más). El hombre trata bien a Tipi y a Topo, pero trata mal a su otro burro.

La situación se repite una última vez con los Martínez:

Los hermanos Martínez son 2 y tienen un burro cada uno (los burros Trini y Troco respectivamente), los cuales a su vez pertenecen también a su padre. Los dos hermanos tratan bien a sus respectivos burros.

El padre de estos dos últimos hermanos tiene tres burros (Trini, Troco y un burro más). El hombre trata bien a Trini y a Troco, pero trata mal a su otro burro.

\section{Pregunta:}

En lo que respecta a esta pequeña aldea, ¿dirías que es cierta la siguiente afirmación?

«En esta aldea, mayoritariamente, si un hombre tiene un burro, lo trata mal.»

Elige la respuesta que te parezca más intuitiva redondeando una sola de las dos opciones que te damos.

$$
\text { SÍ NO }
$$

\section{Contexto y pregunta 2:}

Nos encontramos ahora en otra aldea, también con muy pocos habitantes. De ellos, como antes, 17 son hombres y todos trabajan en el campo con la ayuda de animales. Los 17 hombres tienen cada uno 5 burros y su relación con ellos es la siguiente:

Todos los hombres tratan mal a uno de sus burros y bien a los restantes.

\section{Pregunta:}

En lo que respecta a esta pequeña aldea, ¿dirías que es cierta la siguiente afirmación?

«En esta aldea, mayoritariamente, si un hombre tiene un burro, lo trata mal.»

Elige la respuesta que te parezca más intuitiva redondeando una sola de las dos opciones que te damos.

$$
\text { Sí NO }
$$

\section{TRANSLATION OF THE SECOND CONTEXT}

\section{Context and question 2:}

We are now in another village, also with a very small population. Among them, as before, 17 are men and all of them work the land with the help of animals. The 17 men have 5 donkeys each, and their relation with their donkeys is the following:

All men treat badly one of their donkeys, and well the others. 


\section{Question:}

In which concerns this small village, would you say that the following claim is true?

"In this small village, mostly, if a man owns a donkey, he treats it badly"

Choose the answer that seems more intuitive to you rounding only one of the two options that follows.

\section{YES NO}

\section{THE RESULTS}

Context and question 1 :

\begin{tabular}{ccc}
\hline & Group A & Group B \\
\hline YES & 12 & 24 \\
NO & 6 & 11 \\
\hline
\end{tabular}

Context and question 2:

\begin{tabular}{ccc}
\hline & Group A & Group B \\
\hline YES & 5 & 15 \\
NO & 13 & 20 \\
\hline
\end{tabular}

\begin{tabular}{lcc}
\hline $\begin{array}{l}\text { Answer to question 1: YES } \\
\text { Answer to question 2: NO }\end{array}$ & 8 & 15 \\
\hline $\begin{array}{l}\text { Answer to question 1: YES } \\
\text { Answer to question 2: YES }\end{array}$ & 4 & 9 \\
\hline $\begin{array}{l}\text { Answer to question 1: NO } \\
\text { Answer to question 2: YES }\end{array}$ & 1 & 6 \\
\hline $\begin{array}{l}\text { Answer to question 1: NO } \\
\text { Answer to question 2: NO }\end{array}$ & 5 & 5 \\
\hline
\end{tabular}

Observation: In our experiment we assumed that the intuitive reading of the sentence in the proposed context was the universal one. However even though the data seem mostly to confirm the hypothesis, we can still find participants who seem to make an existential interpretation of the sentence. This is something important to realize indeed, but it does not suppose, we think, a problem for our main conclusion in this article. To justify this claim it is enough to have a look at the following table, where we can find the predicted answers by the different approaches to questions 1 and 2 (answer to question $1 /$ answer to question 2) under a universal and existential reading:

\begin{tabular}{lcc}
\hline \multirow{2}{*}{ Approach } & \multicolumn{2}{c}{ Preferred reading } \\
\cline { 2 - 3 } & Universal & Existential \\
\hline Our approach & YES / NO & YES / YES \\
The (usual) selective quantification approach & NO / NO & YES / YES \\
\hline The non-selective quantification approach & \multicolumn{2}{c}{ NO / NO } \\
\end{tabular}


If we focus among our participants on those who (given the data) may have preferred a universal reading, this is the new table we get:

\begin{tabular}{lcc}
\hline & Group A & Group B \\
\hline $\begin{array}{l}\text { Answer to question 1: YES } \\
\text { Answer to question 2: NO }\end{array}$ & 8 & 15 \\
\hline $\begin{array}{l}\text { Answer to question 1: NO } \\
\text { Answer to question 2: NO }\end{array}$ & 5 & 5 \\
\hline
\end{tabular}

The results seem still to support our approach as the closest one to the intuitions of the speakers.

\section{THE CONTROVERSY}

Probably, the most controversial point about our interpretation of the results, as Reviewer A let us note, rests on our assumption that subjects will use the same reading of the sentence (universal or existential) for judging both questions. This assumption seem to make us difficult to explain the pattern NO / YES of answer that we also obtained in our results.

In section 4 above, we decided to take Geurts (2002) as our main reference in which concerns the existential/universal ambiguity, thus claiming that the preferred interpretation of a conditional donkey sentence depends on the initial adverb (mostly, seldom, etc.) and on world knowledge (what we know, for example, about donkeys, men, about the life in a small village, etc.). In our experiment, we tried to design the two situations and questions in such a way that would fix both variables. So, given a particular subject, his preferred reading in both cases was expected to be the same.

What happened then with those subjects who answered NO / YES to the questions? The total of subjects who answered the questions following this pattern where 7 out of 53 . We do not have a definitive answer here, but one possibility at least to have in mind is that given the difficulty of the first context, these participants just decided to answer randomly to the questions.

\section{REFERENCES}

Barwise, Jon. 1989. The Situation in Logic. Stanford: Center for the Study of Language and Information.

Barwise, Jon and Cooper, Robin. 1981. Generalized quantifiers and natural languages. Linguistic and Philosophy, 4: 159-219.

Bäuerle, Rainer and Egli, Urs. 1985. Anapher, Nominalphrase und Eselssätze. Sonderforschungsbereich 99. Universität Konstanz.

Chierchia, Gennaro. 1992. Anaphora and dynamic binding. Linguistic and Philosophy, 15: 111-183.

Geach, Peter. 1962. Reference and Generality. An Examination of Some Medieval and Modern Theories. Ithaca and London: Cornell University Press.

Geurts, Bart. 2002. Donkey Business. Linguistic and Philosophy, 25: 129-156.

Heim, Irene. 1990. E-Type pronouns and Donkey Anaphora. Linguistic and Philosophy, 13: 137-177.

Hintikka, Jaakko. 1997. No scope for scope? Linguistics and Philosophy, 20: 515-544. 
Kanazawa, Makoto 1994: Weak vs. strong readings of donkey sentences and monotonicity inference in a dynamic setting. Linguistics and Philosophy, 17: 109-158.

King, Jeffrey. 2010. Anaphora. In: Zalta, E.N. (ed.), Ed. Spring 2010 Edition, URL=<http://plato.stanford. edu/archives/spr2010/entries/anaphora/>, Stanford Encyclopedia of Philosophy.

Mann, Allen, Sandu, Gabriel, and Sevenster, Merlijn. 2011. Independence-Friendly Logic. A Game-Theoretic Approach. Cambridge: Cambridge University Press.

Sandu, Gabriel. 1997. On the theory of anaphora: dynamic predicate logic vs. game-theoretical semantics. Linguistic and Philosophy, 20: 147-174.

Schubert, Lenhart, and Pelletier, Francis. 1989. Generically Speaking, or, Using Discourse Representation Theory to Interpret Generics. In: Chierchia, G., Partee B.H., and Turner, R. (eds.), Properties, types and, meaning, volume 2, Dordrecht: Kluwer, pp. 193-268.

van Benthem, Johan. 1984. Foundations of conditional logic. Journal of Philosophical Logic, 13: 303-349.

van Eijck, Jan, and Kamp, Hans. 1997. Representing discourse in context. In: van Benthem, J., and ter Meulen, A. (eds.), Handbook of Logic and Language, The MIT Press, pp. 179-237.

Woods, Michael. 1997. Conditionals. Oxford: Clarendon Press.

Dr. Aránzazu San Ginés is a postdoctoral researcher at the Department of Philosophy I of the University of Granada (Spain). Previously, she was also visiting researcher at IFS-CSIC (Spain), postdoc at Columbia University (USA), and PhD student at IHPST, University of Paris 1 (France), where she successfully defended her dissertation in 2010. She has worked on different topics from natural language semantics, didactics of logic, epistemology, or ethics.

Address: Universidad de Granada. Departamento de Filosofía I, Edificio de la Facultad de Psicología, Campus de la Cartuja, 18011 Granada, Spain. E-mail: aransangines@gmail.com

Dr. María-José Frápolli is Professor of Logic and Philosophy of Science at the Department of Philosophy I, University of Granada (Spain) and currently Marie Skłodowska-Curie Fellow at the Philosophy Department, University College London (UK). She has been Head of the Philosophy Department, University of Granada, from 1998 to 2001 and President of the Society of Logic, Methodology and Philosophy of Science of Spain from 2006 to 2012. Her areas of expertise are Philosophy of Language and Philosophy of Logic. Her Marie Curie Project (EMEHOC) aims to offer an analysis of the meaning of higher-level concepts (truth, knowledge, logical constants) from a pragmatist perspective. Her main semantic background is inferentialist and the approach she defends for higher-level concepts is expressivist in the normative sense.

Address: University College London, Department of Philosophy, Gower Street, London, WC1E 6BT, United Kingdom. E-mail: mjfrapolli@ucl.ac.uk 